\title{
Литература:
}

DUDEK, A. (red.): Czas w kulturze rosyjskiej. Vremja v russkoj kul'ture. Kraków: Wydawnictwo Księgarnia Akademicka, 2019. Seria Antropologia Kultury Rosyjskiej. ISBN 978-83-8138-138-3.

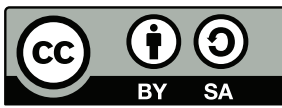

This work can be used in accordance with the Creative Commons BY-SA 4.0 International license terms and conditions (<https://creativecommons.org/licenses/by-sa/4.0/legalcode>). This does not apply to works or elements (such as images or photographs) that are used in the work under a contractual license or exception or limitation to relevant rights.

https://doi.org/10.5817/0S2021-3-12

\section{Eurasijci, Eurasie a eurasijská studia v kontextu ruského světa}

FRIESS, N., KAMINSKIJ, K. (eds): Resignification of borders: Eurasianism and the Russian world. Berlin: Frank \& Timme, Verlag für wissenchaftliche Literatur, 2019. Ost-West-Express, Band 37. ISBN 978-3-7329-0570-6.

„Suddenly, ,Eurasia“ is everywhere“ - tímto postřehem ze studie Stephena Kotkina začíná úvodní článek nové kolektivní monografie věnované problematice eurasijství a koncepci tzv. Ruského světa. Publikace byla sestavená pod editorským dohledem Niny Friess a Konstantina Kaminského, kteří v současnosti působí na Humboldtově univerzitě v Berlíně (Katedra slovanských studii) a přináší řadu tematicky široce uchopených studií, soustředěných na reflexi eurasijských koncepcí zejména v geopolitickém a kulturním areálu Ruska a Střední Asie.

Úvodní editorský článek si klade za cíl nejen stručné představení jednotlivých textů, ale poskytuje i zásadní a metodologicky zajímavě uchopený pohled na eurasijské koncepce a jejích vztah k problematice Ruského světa. Kromě nutného představení eurasijství jako ideologického hnutí, jež vzniklo v prostředí meziválečné ruské emigrace se Friess a Kaminskij soustředili zejména na to, jakým způsobem se v současnosti s tímto termínem operuje v kontextu širšího akademického diskursu. Právě v tomto ohledu je zde citován výše uvedený postřeh Stephena Kotkina, jež v první dekádě 21. století poukázal na výraznou rozpínavost eurasijství nikoliv jako specifické ideologie, ale jako pojmu, jež se zejména v západním akademickém prostředí postupně stal synonymem pro označování post-sovětského geopolitického a kulturního prostoru. 
Ve zdánlivé opozic vůči eurasijství může na první pohled působit koncepce Ruského světa, jež byla zformulována již v průběhu 8o. let 20. století ale zásadního významu nabyla až na počátku 21. století, kdy získala $v$ Rusku podobu jakési oficiální soft power strategie. V současnosti je tato iniciativa zastřešená zejména Nadací Ruského světa, jež by se dala připodobnit např́klad k organizaci British Council nebo ke Goethe-Institutu. Friess a Kaminskij ovšem zdůrazňuji že mezi eurasijstvím a Ruskými světem je možné najít řadu styčných bodů což zřetelně ilustruji i jednotlivé texty dané monografie.

Problematice Ruského světa v širším areálu východní Eurasie Konstantin Kaminskij věnoval samostatný článek. Jeho studie se soustředila na environmentální aspekty dané oblasti a reflexi této problematiky v rámci intelektuálního odkazu sovětského historika Lva Nikolajeviče Gumiljova.

Nina Friess se k otázkou Ruského světa zabývala v rámci analýzy nové rusofonní literatury v Kazachstánu. Autorka se zaměřila na postavení rusky píšících kazašských autorů ke koncepci Ruského světa a poukázala na mechanismy s jejichž pomocí tito autoři využívají danou koncepci v rámci propagace vlastních idejí potenciálnímu ruskojazyčnému publiku, jehož počet daleko přesahuje domácí čtenářkou základnu Kazachstánu.

Velmi př́nosnými se jeví také dvě studie, jež reflektuji problematiku Ruského světa a eurasijství v kontextu islámského kulturně-ekonomického prostředí. Victoria Abakumovskikh se zde soustředila na analýzu specifického islámského ekonomického modelu Tatarstanu. Autorka zde poukázala především na úzké propojení mezi islámským náboženstvím jako stavebním kamenem tatarské národní identity a jeho politickými a ekonomickými konotacemi. Specifiky islámského eurasijství se zabývala také dvojíce autorů Gulnaz Sibgatulina a Michael Kemper, kteří ve společném článku přibližili ambivalentní postoj ruských neoeurasijců $\mathrm{k}$ islámskému náboženství a současně se pokusili popsat poněkud paradoxní implementaci eurasijství jako primárně imperiální ideologie úzce propojení s pravoslavím v textech současných předních islámských intelektuálů.

Eurasijství v ruskému kulturním a geopolitickém kontextu jsou v monografii věnovány tři studie. První $\mathrm{z}$ nich se soustředila na srovnání eurasijského imperialismu a západního universalismu v kontextu meziválečného eurasijství 2o. let 20. století. Erik Martin zde srovnal revisionistické eurasijské teze Nikolaje Sergejeviče Trubeckého s koncepcemi historika Michaila Ivanoviče Rostovceva a zasadil je do širšího kontextu ruského emigrantského intelektuálního myšlení první poloviny 2o. století. Druhá studie je věnována publicistickým textům Eduarda Limonova - zakladatele Nacionálně bolševické strany Ruska. Anna Razuvalova se v tomto př́padě zaměřila především na intelektuální východiska Limonova a jeho kontakt Aleksandrem Duginem další kontroverzní postavou ruského intelektuální prostředí a přední osobností tzv. neoeurasijského hnutí. Obě osobnosti Razuvalova ve výsledku zařadila mezi zástupce 
tzv. neokonzervativismu jehož výchozí teze se v současném Rusku úzce prolínají s myšlenkami neoeurasijců i s některými aspekty Ruského světa.

Poslední text věnovaný ruskému eurasijství je zaměřen na reflexi dané koncepce v současné ruské literatuře. Clemens Günther a Svetlana Sirotinina zde zdůraznili, že v literárním prostředí mají eurasijské koncepce velmi široké ideové rozpětí, jež daleko přsahuje tradiční vnímání eurasijství jako výlučně geopolitické ideologie, zformované v prostředí ruské meziválečné emigrace. Při analýze vybraných děl reflektujících eurasijskou problematiku Günther a Sirotinina vymezili přinejmenším pět specifických koncepčních př́istupů k dané problematice (imperiální eurasijství, ironické eurasijství, postkoloniální eurasijství, regionální eurasijství a biografické eurasijství).

V širším kontextu tato i všechny další výše uvedené studie zřetelně reflektuji velmi výraznou plasticitu a ohebnost eurasijských koncepcí nejen v rámci jejich praktické implementace $\mathrm{v}$ kontextu postsovětského politického, ekonomického a kulturního areálu, ale také ve specifikách akademického výzkum dané problematiky. V tomto kontextu monografie velmi zdařile reflektuje šiří a komplexnost eurasijství a Ruského světa a přináší do jejích odborného výzkumu množství nových tematických i metodologických podnětů.

Michal Racyn

\section{Literatura:}

FRIESS, N., KAMINSKIJ, K. (eds): Resignification of borders: Eurasianism and the Russian world. Berlin: Frank \& Timme, Verlag für wissenchaftliche Literatur, 2019. Ost-West-Express, Band 37. ISBN 978-3-7329-0570-6.



Toto dílo Ize užít v souladu s licenčními podmínkami Creative Commons BY-SA 4.0 International (<https:// creativecommons.org/licenses/by-sa/4.0/legalcode>). Uvedené se nevztahuje na díla či prvky (např. obrazovou či fotografickou dokumentaci), které jsou v díle užity na základě smluvní licence nebo výjimky či omezení príslušných práv. 